Andrykiewicz A., Integrated product policy in the process of developing the pro-environmental consumer attitude in the given European Union countries, „Economics and Law”, Polszakiewicz B., Boehlke J. (ed.), Vol. 13, No. 1/2014, pp. 27-36. DOI: http://dx.doi.org/10.12775/EiP.2014.002.

\title{
INTEGRATED PRODUCT POLICY IN THE PROCESS OF DEVELOPING THE PRO-ENVIRONMENTAL CONSUMER ATTITUDE IN THE GIVEN EUROPEAN UNION COUNTRIES $\diamond$
}

\author{
SUMMARY
}

This article offers possibilities to reduce the negative affect industrial products have on the environment, for which products' life span has significantly shortened within the last twenty years. The influence tools designed by the European Commission within the Integrated Product Policy (IPP) are very effective on institutional entities. They were evaluated through their impact on the consumer attitudes of the Polish, German and Belgian citizens. It was concluded, based on empirical research, that the main criteria in the process of purchase decision-making are quality, price and functionality, but there were also communities identified, for which the social proof criteria is the priority. The pro ecology changes in the educational system for children and youth, as well as the social campaigns promoting the sustainable consumption among the citizens of the European Union will increase the implementation of the IPP. The correlation between the quality, price and environment would be most favorable.

Anna Andrykiewicz, University of Zielona Góra, Faculty of Economy and Management, ul. Pogdórna 50, 65-246 Zielona Góra, phone: +48 6832825 55, e-mail: anna.andrykiewicz@ gmail.com.

$\diamond$ The scientific research financed by the financial resources for studies for the years 2012-2013 as a research project within the "Diamond Grant" program. 
The thesis consist of two chapters and a subchapter. The first chapter describes the reasons for creating the IPP, as well as its tools and the level of their implementation. The second chapter brings up the concept of the sustainable consumption, the meaning of the Earth Summit in Rio de Janeiro which was about the environment and the development, and it includes the reference to the documents of the Union. It analyses the role of business and the consumers in the implementation of the sustainable development. The subchapter consists of research on the sustainable consumption conducted on individual consumers.

Keywords: sustainable development, sustainable consumption, Life Cycle Assessment, Corporate Social Responsibility

JEL Classification: D11, D12, O44, Q01

\section{INTRODUCTION}

Consumption is an important element of the economic and social processes. It influences the environment. The knowledge of those phenomena is the basis for the understanding of the existing consumer behavior models. Learning about the relations present in the market, between its particular members, brings us closer to the structure of the sustainable consumption paradigm (The Ministry of Economy defines the sustainable consumption in the document entitled: Through the sustainable consumption to the sustainable development by the most favorable, conscious and responsible use of the natural resources, foods and services on the individual level, households and local communities, business environments, local governments, national governments and international structures, in accordance with the rules of the sustainable development), which could be commonly used. This model, next to the utilitarian aspects, such as meeting the needs of the present the future generations, as well as increasing the quality of life locally and globally, may limit the prodigality, production of wastes and pollution.

The Integrated Product Policy (IPP) is the European Commission and its member countries' strategy based on creating the conditions for the dynamic development and the economic growth, by using tools which will allow for harmonizing the needs in the economic and social spheres, as well as the best preservation of natural environment. The consumers' attitude, their environmental awareness, as well as their knowledge they acquire through education and the social campaigns are the key elements in implementing the IPP.

The article draws attention to the degree of implication Integrated Product Policy in relation to the consumers, including institutional and role of the European Union in promoting sustainable consumption. As part of the study 
was based on primary and secondary sources, literature on the subject, as well as documents produced by the European Union.

\section{THE INTEGRATED PRODUCT POLICY AS THE STIMULUS FACTOR FOR THE SUSTAINABLE CONSUMER ATTITUDE}

The technological development and the development of the new industries have caused the increase of production and the decreased life span of the products. The European Commission, observing this process in 1997, decided to start working on the Integrated Product Policy, which tools would help implement the monitoring and reducing the negative effect on the environment methods, throughout the whole life of a product. The document was accepted in 2003, and the Union's countries were obligated to implement it. The national strategies had to include communizing the ecolabel as well as the environmental management in the businesses and organizations - EMAS (Eco Management and Audit Scheme), using the ecological criteria at publically funded tendering, environmental taxes, the understanding between the business people and the public authorities, accounting including all production costs, as well as ensuring the access to the environmental information regarding the product, and communizing the environmental declarations for the products ${ }^{1}$. The particular tools differ from each other by the level of implementation and the effectiveness of their influence. The obligatory tools, such as taxes or in many EU countries the green public procurements are more effective and are easier to monitor (Public Institutions in the EU countries have a high purchasing Power and spend about 2 trillion EURO a year, which is $19 \%$ of the EU Gross Domestic Product value). It is completely different with the ecomarking and the ecolabeling from the definition of the voluntary tools of influence. The individual consumers distinguish on average 5 basic labels, which are given most attention in the particular region, being a rather small percentage of the general number of symbols. The tendency of seeking the organic ("BIO") products is visible, as well as what a particular product consists of, and what country it comes from.

The European Union implemented the Environmental Management System and the EMAS in 1995 for the purpose of developing the environmental policy in businesses. It's main objectives are: the systematic increase of the

\footnotetext{
${ }^{1}$ Komisja Europejska, Komunikat Komisji Europejskiej dla Rady i Parlamentu Europejskiego, Zintegrowana Polityka Produktowa - Wykorzystanie podejscia środowiskowego opartego na analizie cyklu życia produktu, COM (2003) 302.
} 
effects of the pro-environmental activities of the organization, which will ensure a better position in the market, compliance with the environmental protection provisions of law on the level of the country and the union, including the employees and the stakeholders in the particular phases of the activities and the information about the effects of the environmental activity ${ }^{2}$. In the first phase of the program functioning, it included only the manufacturing companies, but starting from 2001 it became accessible to all organizations. The statistics of the Department for Environment of the EU show, that in the year of 2013 - 3776 organizations use the system, and to compare, in the year of 1997 there were 2140 companies using it. The biggest number of the registered organizations are in Italy (1224), Spain (992), and in Germany (861) ${ }^{3}$. These numbers indicate how adaptable is the system of the green procurements, which are prefered by the organizations registered in the EMAS. There have not been created any appropriate tools to stimulate the rest of the Unions countries to join the program. The most important tool of the Integrated Product Policy is the ecologic assessment of the life cycle (LCA), which includes:

- The assessment of the environmntal issues regarding the designing and the manufacturing process, based on the use of energy and materials as well as the environmentally damaging emissions;

- The assessement of the product's impact on the environment;

- The assessment of the potencial improvement of the environment ${ }^{4}$.

The social campaigns based on the partnership between businesses, public authorities and the non-govermental organizations are more and more effective in regards to the consumer awareness. The educational programs have started including the socially important issues regarding the rational management of the natural goods, wastes recycling, as well as respecting the people and their work.

The worth mentioning initiative of the European Commission is collecting the best practices from all the EU countries regarding the implementation of the IPP tools. They are published in the Ecological shopping, a textbook published by the UC, as well as the reports on the policy of the sustainable development. Usually they are regarding the utilization of the green pub-

2 Parlament Europejski, Rozporządzenie Parlamentu Europejskiego i Rady (WE) nr 1221/2009 $z$ dnia 15.11.2009 r. w sprawie dobrowolnego udziatu organizacji w systemie ekozarzadzania $i$ audytu we Wspólnocie (EMAS).

${ }_{3}$ European Commission, EMAS Statistics and Graphs, http://ec.europa.eu/environment/ emas/ (30.05.2013).

${ }^{4}$ W. Adamczyk, Ekologia wyrobów, PWE, Warszawa 2004, p. 26. 
lic procurements and the public business responsibility. The egzample of such activity was the purchase of the computer hardware in Munich, in 2010. The requirements of the tender were prepared based on the Blue Angle and Eco Star lables. They included many environmental criteria regarding the energy efficiency, noise emmission, and the utilization of the harmfull substances. The highest profitability of the offer was calculated based on the points awarded for the environmental factors and the quality, devided by the price ${ }^{5}$.

\section{THE CONCEPT OF THE SUSTAINABLE CONSUMPTION}

The United Nations Conference was held in Rio de Janeiro in 1992 regarding the Environment and the Development. Representatives of 172 governments took part in the meeting. Four main documents were created and approved: The United Nations Framework Convention on Climate Change, Agenda 21, the Convention regarding the preservation of the biological diversity and the Convention regarding the direction of the development, the conservation and the use of forests. They became the basis for creating the sustainable economic, social, and environmental policy, as well as the concept of the sustainable consumption. The European Commission, having the international arrangement in mind, has created solutions for optimizing the previously adopted solutions, which are included in its key strategies and regulations: Lisbon Strategy, the EU Sustainable Development Strategy, the Integrated Product Policy, and Building based on the Life Cycle Methodology, COM (2003) 302, Activity Plan for the sustainable consumption and production, and the sustainable industry policy, COM (2008) 397 and Europe 2020. These documents make the common policy of the EU countries regarding obtaining the natural goods and their rational utilization, as well as creating the sustainable consumption patterns among the EU citizens.

Besides the legislative and executive bodies, the business people, who introduce products and services into the market, play an important role. They are responsible for the entire production process, from designing, through obtaining materials for the particular product, production, distribution, to utilization and elimination of the post-consumer waste or recycling after use. They also support the campaigns, influence the consumers creating the need for particular goods. That is why throughout the past ten years more and more is talked about the Corporate Social Responsibility (CSR) and its role in the

${ }^{5}$ Komisja Europejska, Ekologiczne Zakupy, wyd. 2, Luksemburg: Urząd Publikacji Unii Europejskiej 2011. 
implementation of the social goals and the preservation of the natural environment. Companies support the ethical behavior and the responsibility for their stakeholders, they build their relationships based on trust and respect for the people and their work. From the perspective of the local communities, it is important to take the initiative for the purpose of improving the citizens quality of life. Engaging the company's employees through voluntary work not only influences the company's image, but also brings them closer as a team, where work brings more satisfaction. The research commissioned by the European Commission on competitiveness in 2008 shows, that the organizations having a social responsibility have more potential than the other companies to manage the risk, approach the costs more economically, have better relations with clients, effectively manage the human resources and engage in the innovative projects ${ }^{6}$. The efforts to provide the consumers with the sustainable development and the sustainable consumption objectives contribute to the consumers making more conscious choices, analyzing their needs, and managing their life style with more awareness. Informing the consumers about their rights and possibilities make the consumption more responsible.

The aware consumer may influence the global processes happening in the economy and in the society: the preservation of the natural environment, protection of human and employees rights. Through making decisions, the consumer influences fair competition and creation of positive consumption patterns, which are: purchasing the products with the ecolabelling, supporting the Fair Triad idea, paying attention to the social campaigns and the socially engaged marketing, as well as taking part in the discussions regarding the activities of different companies, using the official communication channels to communicate with them for the purpose of influencing their policy ${ }^{7}$.

\subsection{RESEARCH ON SUSTAINABLE CONSUMPTION}

In the first half of 2011 the European Commission for the first time asked the consumers, in the $5^{\text {th }}$ edition of the "Consumer Markets Results Table", whether, while making a decision about a purchase, they take under their consideration the way the product purchased by them influences the environment. The average result of the positive answers in the entire European Union

${ }^{6}$ Komisja Europejska, Komunikat Komisji Europejskiej w sprawie sprawozdania na temat europejskiej konkurencyjności w 2008 r., COM (2008) 774.

7 Komisja Europejska, Komunikat Komisji Europejskiej dla Rady i Parlamentu Europejskiego, Odnowiona strategii UE na lata 2011-2014 dotyczaca spotecznej odpowiedzialności przedsiębiorstw, $\operatorname{COM}(2011) 681$. 
was $32 \%$, the Polish consumers came under the average answering positively at $27 \%{ }^{8}$. That same year, in late April and early May, the Eurobarometer conducted a research regarding the European citizens attitude towards the environment, in which $68 \%$ of the Polish respondents think, that the citizens do not take sufficient measures to efficiently use the natural resources. Large percentage of the respondents think also, that the government acts insufficiently in this measure. The Polish people are mostly concerned about the wastes $(52 \%)$ and the air pollution $(40 \%)^{9}$.

In the beginning of 2013, a research was conducted in three chosen countries of the EU: Belgium, Germany and Poland, regarding the identification of the ecologic factor perception as the consumer choice criterion (This research was designer at the University of Zielona Góra through the Diamond Grant program, and it quantity oriented. It was conducted on a group of 900 randomly chosen consumer. The respondents ware differentiated based on the social-demographic factors, such as: age, sex, education, address, funds for consumption. The statistical analysis were prepared in the $\mathrm{R}$ program ${ }^{10}$ ). The respondents were asked to designate value (from 1 to 5 , where 1 meant the most import ant criterion while ma king the decision) to the criteria they take into consideration (price, quality, environment, functionality, fashion) while making a decision about purchasing a product. Statistically the respondents placed the quality as the first criterion, and then price, functionality, environment and fashion. There were discrepancies from this hierarchy though depending on the social-demographic characteristics.

Table 1. Distribution of the choice criteria based on the country

\begin{tabular}{|c|c|c|c|c|c|}
\hline $\begin{array}{c}\text { CRITERION/ } \\
\text { COUnTRY }\end{array}$ & PRICE & QUALITY & ENVIRONMENT & FunCtIONALITY & FASHION \\
\hline Belgium & 2.46 & 1.88 & 3.86 & 2.52 & 4.28 \\
\hline Germany & 2.22 & 2.24 & 3.65 & 3.12 & 3.77 \\
\hline Poland & 2.41 & 1.93 & 3.82 & 2.63 & 4.21 \\
\hline general & 2.36 & 2.02 & 3.78 & 2.76 & 4.09 \\
\hline
\end{tabular}

Source: Own research conducted within the Diamond Grant.

${ }^{8}$ European Commission, Consumer Conditions Scoreboard - Consumers at home in the single market, SEC(2011) 299.

${ }^{9}$ Federacja Konsumentów, Zrównoważona konsumpcja: czy konsumenci sa gotowi jq zaakceptować?, http://www.federacja-konsumentow.org.pl/story.php?story=832 (2.06.2013).

${ }^{10}$ A.D. Aczel, Complete Business Statistics, Second Edition, Richard D. Irwin, 1993. 
The monthly budget for consumption and educating the respondents were the characteristics, which influenced the different values. The Polish and German citizens' budgets for consumption above the national average, placed the environment criterion on the $3^{\text {rd }}$ place. The higher the education of the Belgian consumers, the more important the environment criterion was; in Poland it was the other way around, the higher education, the lesser value was designated for the environment. This result may be due to educational programs in both countries. In Belgium, in the 80's of the twentieth century in schools and universitys were taught about ecolabelling and promoted by sustainable consumption. In Poland this subject has become popular since our accession to European Union, a level of awareness for education was formed this time and is being created till now.

The address (village, city up to 20 thousand people, city between 20 thousand and 100 thousand, city between 100 thousand to 500 thousand, and the cities above 500 thousand) and the subjective assessment of the economic situation showed similar values resembling the main hierarchy. The sex did not constitute any differentiating factors, because the response of the women and men were similar in percentage. There were differences in the responses of the German consumers in the price criterion ( $\mathrm{W}-2.34, \mathrm{M}-2.07$ ) and fashion (W - 3.62, M - 3.95), which resulted the German men placing the price first and then the quality, conversely to the other respondents.

Regular testing is able to demonstrate that trends in the consumer criteria are continue, or appears agents that translate into their changes, such as lifestyle or promotions pro-environmental organizations.

Table 2. Distribution of the choice criteria based on the country and the sex type of the respondents

\begin{tabular}{|c|c|c|c|c|}
\hline CRITERION & SEX & BELGIUM & GERMANY & POLAND \\
\hline \multirow{3}{*}{ price } & $\mathrm{W}$ & 2.44 & 2.34 & 2.33 \\
\cline { 2 - 5 } & $\mathrm{M}$ & 2.47 & 2.07 & 2.49 \\
\hline \multirow{3}{*}{ quality } & $\mathrm{W}$ & 1.89 & 2.27 & 1.91 \\
\cline { 2 - 5 } & $\mathrm{M}$ & 1.87 & 2.20 & 1.95 \\
\hline \multirow{2}{*}{ environment } & $\mathrm{W}$ & 4.02 & 3.65 & 3.96 \\
\cline { 2 - 5 } & $\mathrm{M}$ & 3.66 & 3.65 & 3.68 \\
\hline \multirow{2}{*}{ functionality } & $\mathrm{W}$ & 2.51 & 3.12 & 2.65 \\
\cline { 2 - 5 } & $\mathrm{M}$ & 2.53 & 3.12 & 2.61 \\
\hline \multirow{2}{*}{ fashion } & $\mathrm{W}$ & 4.13 & 3.62 & 4.15 \\
\cline { 2 - 5 } & $\mathrm{M}$ & 4.47 & 3.95 & 4.27 \\
\hline
\end{tabular}

Source: Own research conducted within the Diamond Grant. 


\section{CONCLUSIONS}

The rational utilization of the IPP tools and the permanent analysis will ensure the optimization of the utilization of the natural resources, most of all the nonrenewable. Having in mind the ecological assessment of the life cycle and the good practices from different regions will help create common solutions adequate to the needs of the entire the EU. The especially big challenge is economic utilization of the resources and their reuse. The permanent process of innovation is on one side the success of the civilization, increases the quality of life and leads to the economic growth, on the other hand it often has a negative effect on the environment. The scientific research plays a significantly important role as it engulfs the Integrated Product Policy tools as a whole. Engaging the industry in the popularization of the idea of the sustainable development is an undertaking which shapes the consumer attitudes, including the more responsible behaviors. Not without a reason there is a concern for the environment criterion in the process of the decision making regarding a purchase. The research studies conducted on a group of Europeans from Poland, Belgium and Germany show, that the quality, price and functionality are still more important than the environment. Still the quality research indicate the existence of certain groups (sports people, mothers with little children, chronically ill people, the residents of protected areas on the grounds of the natural conditions), which classify the environmental criteria above. Further studies are warranted to demonstrate whether over time hierarchy of criteria will change and if so, what are the reasons for the change. Popularization of the knowledge regarding the sustainable consumption has an essential meaning for the present and the future generations, and it is important to maintain balance between the social values, environment, and economy, which will allow for creating the solutions for the needs of the contemporary civilization.

\section{BIBLIOGRAPHY}

Aczel A.D., Complete Business Statistics, Second Edition, Richard D. Irwin, 1993. Adamczyk W., Ekologia wyrobórw, PWE, Warszawa 2004.

European Commission, Consumer Conditions Scoreboard - Consumers at home in the single market, SEC(2011) 299.

European Commission, EMAS Statistics and Graphs, http://ec.europa.eu/environment/ emas/ (30.05.2013). 
Federacja Konsumentów, Zrównoważona konsumpcja: czy konsumenci sq gotowi ja zaakceptować? http://www.federacja-konsumentow.org.pl/story.php?story=832 (2.06.2013).

Komisja Europejska, Ekologiczne Zakupy, wyd. 2, Luksemburg: Urząd Publikacji Unii Europejskiej 2011.

Komisja Europejska, Komunikat Komisji Europejskiej dla Rady i Parlamentu Europejskiego, Odnowiona strategii UE na lata 2011-2014 dotyczaca spotecznej odpowiedzialności przedsiębiorstw, $\mathrm{COM}(2011) 681$.

Komisja Europejska, Komunikat Komisji Europejskiej dla Rady i Parlamentu Europejskiego, Zintegrowana Polityka Produktowa - Wykorzystanie podejścia środowiskowego opartego na analizie cyklu życia produktu, COM (2003) 302.

Komisja Europejska, Komunikat Komisji Europejskiej w sprawie sprawozdania na temat europejskiej konkurencyjności w 2008 r., COM (2008) 774.

Parlament Europejski, Rozporzadzenie Parlamentu Europejskiego i Rady (WE) nr 1221/2009 z dnia 15.11.2009 r. w sprawie dobrowolnego udziatu organizacji w systemie ekozarządzania i audytu we Wspólnocie (EMAS). 